\title{
Sunlight Irradiation Reactions of Methoxylated Dibenzylideneacetone with Group 6 and 8 Metal Carbonyl Complexes: Synthesis, Characterization, Spectral Investigation and Biological Activities
}

\author{
Ramadan M. Ramadan, Mostafa M.H. Khalil, Mounir A.I. Salem*, Magda I. Marzouk, \\ Mohamed S. Moftah \\ Department of Chemistry, Faculty of Science, Ain Shams University, Abbassia, 11566, Cairo. Egypt.
}

\section{A R T I C L E I N F O}

Article history:

Received 24 March 2011

Accepted 17 May 2011

Keywords:

1,5-bis(3,4-methoxyphenyl)penta-(1E,4E)-1,4-dien-3-one;

Metal carbonyls;

Sunlight irradiation reactions;

EI-fragmentation;

Methoxylated dibezylidene acetone (mdba) antibacterial activity.

\begin{abstract}
A B S T R A C T
Sunlight irradiation of the reactions of either $\left[\mathrm{M}(\mathrm{CO})_{6}\right], \mathrm{M}=\mathrm{Cr}$, Mo and $\mathrm{W}$ or $\left[\mathrm{M}_{3}(\mathrm{CO})_{12}\right], \mathrm{M}=\mathrm{Ru}$ or Os with methoxylated dibenzylideneacetone; 1,5-bis(3,4methoxyphenyl)-penta-(1E,4E)-1,4-dien-3-one (mdba) in benzene were investigated. While a mononuclear oxo-chromium complex with molecular formula $\left[\mathrm{CrO}(\mathrm{mdba}-\mathrm{H})_{2}\right], 2$ was obtained, two dinuclear complexes with molecular formulas $\left[\mathrm{Mo}_{2} \mathrm{O}_{2}(\mathrm{mdba}-\mathrm{H})_{2}\right], 3,\left[\mathrm{~W}_{2} \mathrm{O}_{4}(\mathrm{mdba}-\mathrm{H})_{2}\right]$, 4, were isolated. The corresponding photochemical reactions of mdba with group 8 cluster complexes produced the complexes, $\left[\mathrm{Ru}_{3}(\mathrm{CO})_{6}(\mathrm{mdba}-\mathrm{H})_{2}\right]$, 5, and $\left[\mathrm{Os}_{3}(\mathrm{CO})_{6-}\right.$ (mdba-H $)_{2}$ ], 6, with one Ru-Ru bond breaking. The organic ligand in complexes realizes different coordination modes. With group 6 metal carbonyls, the ligand behaves as bidentate where it coordinate to the metal through keto group and a carbon from ethylene group after loss of one proton forming five-membered ring. On other hand, with group 8 metal carbonyls the olefin bond of the ligand participate in coordination in addition to the coordination through keto group and a carbon of ethylene group with loss of one proton. All complexes were characterized by elemental analysis, infrared, mass, ESR, ${ }^{1} \mathrm{H}$ NMR and ${ }^{13} \mathrm{C}-\mathrm{NMR}$ spectroscopy. The UV-vis spectra of the complexes showed shift in the visible band of the ligand due to coordination. Thermal properties of the complexes were investigated by TG thermogravimetry technique. The synthesized mdba ligand and its complexes were screened for their antibacterial activity against two gram positive bacteria, two gram negative bacteria and fungi candida albicans. The activity was compared with standard Amikacin.
\end{abstract}

\section{Introduction}

Transition metal complexes of $\alpha, \beta$-unsaturated ketones are important intermediate in the synthesis of organic products such as $\beta$-lactames, amino acids, and heterocyclic compounds. However, coordination of these ligands with transiton metals are scarce, although the presence of the conjugated $\mathrm{C}=\mathrm{O}$ ketone and $\mathrm{C}=\mathrm{C}$ double bond in these molecules may lead to a wide reactivity and various coordination patterns.

Osintseva et $\mathrm{al}^{1-6}$ carried out a series of studies on the reactivities of $\alpha, \beta$-unsaturated carbonyl compounds in thermal reactions with ruthenium carbonyls. The reactions of $\mathrm{Ru}_{3}(\mathrm{CO})_{12}$ with 4-phenylbut-3-en-2-one, 3-

\footnotetext{
* Corresponding author.

E-mail address: Salemmai1947 @ yahoo.com.
}

phenyl-1-p-tolyl-prop-2-en-1-one, and 1,3-diferrocenylprop-2-en-1-one afforded bi- and trinuclear complexes with the $\eta 3$-coordinated five-membered oxaruthenacycles $\mathrm{Ru}_{2}(\mathrm{CO})_{6}(\mu-\mathrm{H})\left(\mathrm{O}=\mathrm{C}\left(\mathrm{R}_{1}\right) \mathrm{C}(\mathrm{H})=\mathrm{C}\left(\mathrm{R}_{2}\right)\right)$ and $\mathrm{Ru}_{3}(\mathrm{CO})_{8}\left(\mathrm{O}=\mathrm{C}\left(\mathrm{R}_{1}\right) \mathrm{C}(\mathrm{H})=\mathrm{C}\left(\mathrm{R}_{2}\right)\right)_{2}$ as the major products. On the other hand, the dibenylideneacetone (dba) ligand provides a series of zerovalent $\mathrm{Pt}$ and $\mathrm{Pd}$ complexes in which only the olifenic double bond participate in bonding to the metal. The binuclear complexes, $\mathrm{M}_{2}(\mathrm{dba})_{3}(\mathrm{M}=\mathrm{Pd}, \mathrm{Pt})$, retain a rigid structure, even in solution, where the two olefinic double bonds of dpa are separately joined to the two metal atoms ${ }^{7,8}$. The mononuclear complexes, $\mathrm{M}(\mathrm{dpa})_{3}$ $(\mathrm{M}=\mathrm{Pd}, \mathrm{Pt})$, are expected to be in a more flexible form because of olefinic free from coordination. 
Many research papers were published for the structure and conformation of $\mathrm{Pt}$ and $\mathrm{Pd}$ zerovalent with the parent compound dibenzylideneacetone, dba. ${ }^{9}$.

There is a great interest in the curcumin derivatives of analogues of 1,5-bis(3,4-methoxyphenyl)-penta(1E,4E)-1,4-dien-3-one (C(5)-curcumin), because of their cytotoxicities against human colon cancer cell line HCT $-116^{10,11}$. Also they showed significant cytotoxicity against both human prostate and breast cancer cell lines ${ }^{12}$. The previous studies indicated the importance of 3',4'-disubstitution on the phenyl rings for the activity of $\alpha, \beta$-unsaturated ketones in the synthesis of variety of organic products having different applications ${ }^{13-16}$.

Recently, we studied the reaction of (2'-hydroxyphenyl)3-(3'-4'-dimethoxyphenyl)propen-1-one ( $\mathrm{ChOH})$ with metal carbonyl complexes of group 6 and 8 under sunlight irradiation. Three dinuclear complexes with molecular formulas $\left[\mathrm{Cr}_{2} \mathrm{O}_{2}(\mathrm{ChO})_{2}\right],\left[\mathrm{Mo}_{2} \mathrm{O}_{4}(\mathrm{ChO})_{2}\right]$ and $\left[\mathrm{W}_{2} \mathrm{O}_{4}(\mathrm{ChO})_{2}\right]$ were isolated. The corresponding reactions of the $\mathrm{ChOH}$ with group 8 cluster complexes produced the complexes, $\left[\mathrm{Ru}_{3}(\mathrm{CO})_{10}(\mathrm{ChO})\right]$, and $\left[\mathrm{Os}_{3}(\mathrm{CO})_{10}(\mathrm{ChOH})\right]^{17}$.

In the present work, the photochemical reactions of 1,5bis(3,4-methoxyphenyl)-penta-(1E,4E)-1,4-dien-3-one with metal carbonyl complexes of group 6 and 8 under sunlight irradiation were studied.

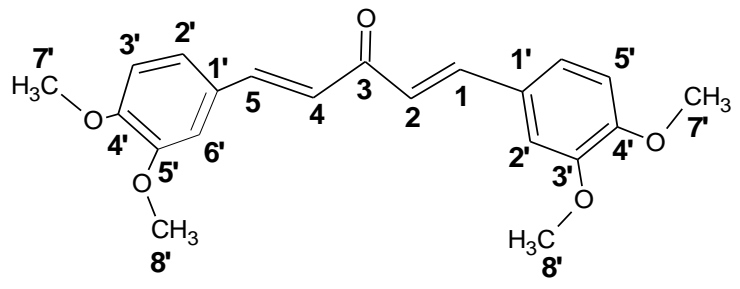

(mdba), 1

\section{Experimental procedures}

\section{Chemicals}

$\mathrm{M}(\mathrm{CO})_{6} ; \mathrm{M}=\mathrm{Cr}$, Mo or $\mathrm{W}, \mathrm{M}_{3}(\mathrm{CO})_{12} ; \mathrm{M}=\mathrm{Ru}$ or Os and 3,4-dimethoxybenzaldehyde were purchased from Aldrich. All solvents were of analytical grade and were purified by distillation before use.

\section{Instrumentation}

Infrared measurements were carried out on a UnicamMattson 1000 FTIR spectrometer using $\mathrm{KBr}$ pellets. Nuclear magnetic resonance measurements were performed on a Spectrospin-Bruker AC $300 \mathrm{MHz}$ for ${ }^{1} \mathrm{H}-\mathrm{NMR}$ and $75.45 \mathrm{MHz}$ for ${ }^{13} \mathrm{C}-\mathrm{NMR}$ spectrometer. Samples were dissolved in DMSO- $\mathrm{d}_{6}$ using TMS as internal reference. UV-vis measurements were carried out on a Unicam UV2-300 spectrophotometer with 10 $\mathrm{mm}$ quartz cell. Magnetic susceptibility of the paramagnetic complexes in the solid state (Gouy method) was recorded on a Sherwood magnetic susceptibility balance. Diamagnetic correction was made by Pascal's constant and $\mathrm{Hg}\left[\mathrm{Co}(\mathrm{SCN})_{4}\right]$ was used as a calibrant. Mass spectra of the solid complexes $(70 \mathrm{eV}$, EI) were carried out on a Shimadzu Qp-2010 Plus spectrometer. Thermogravimetric analyses were carried out under nitrogen atmosphere with a heating rate of $10^{\circ} \mathrm{C} / \mathrm{min}$ using a Schimadzu DT-50 thermal analyzer. Elemental analyses were performed on a Perkin-Elmer $2400 \mathrm{CHN}$ elemental analyzer. All the measurements were carried out in the Central Laboratory of Microanalysis, Cairo University.

Synthesis of (1E,4E)-1,5-bis-(3,4-dimethoxyphenyl) penta-1,4-dien-3-one

In a $500 \mathrm{ml}$ wide-mouthed reagent bottle place a cold solution of (0.02 mole) sodium hydroxide in $100 \mathrm{ml}$ water and $80 \mathrm{ml}$ ethanol with mechanical stirrer and the bottle put in water bath to maintain the temperature solution at $\left(20-25^{\circ} \mathrm{C}\right)$. Stir vigorously and add one-half of a previously prepared mixture of $(7.0 \mathrm{gm}, 0.02 \mathrm{~mol})$ of 3,4-dimethoxybenzaldehyde and $6 \mathrm{ml}(0.01 \mathrm{~mol})$ acetone. A flocculent precipitate forms in 2-3 minutes. After $15 \mathrm{~min}$, add the remainder of the 3,4dimethoxybenzaldehyde-acetone mixture. Continue stirring for further $15 \mathrm{~min}$ at the pump and wash with cold water to eliminate the alkali as completely as possible. Dry the solid at room temperature upon filter paper. The solid was recrystallized from ethanol (yield $86 \%$ ), m.p. $=72-74$.

\section{Synthesis of the complexes}

A general procedure was employed for the synthesis of the reported complexes. A mixture of equimolar amounts of $\left[\mathrm{M}(\mathrm{CO})_{6}\right], \mathrm{M}=\mathrm{Cr}$, Mo and $\mathrm{W}$, or $\left[\mathrm{M}_{3}(\mathrm{CO})_{12}\right]$ and mdba in a sealed glass (Pyrix) tube (150ml) containing $25 \mathrm{ml}$ of dry benzene. Photolysis of the mixture with sunlight irradiation for a certain period of time at $\left(25 \pm 5^{\circ} \mathrm{C}\right)$ in summer months was employed. The photoexcitation procedure is expected to be the UV range of light $\left(850-1000 \mathrm{~W} / \mathrm{m}^{2}\right)$. At the end of the reaction, the solvent was removed on a vacuum line. The residue was washed several times by boiling petroleum ether (b.p. 60/80) and then recrystallized from ethanol. The complex was left to dry in vacuo for several hours. Table 1 gives the reaction period, colour, yield and melting points of the complexes.

\section{Antimicrobial activity}

The ligand and its complexes were screened for their antibacterial activity using the agar diffusion technique $^{18}$. A $2.5 \mathrm{mg} / \mathrm{ml}$ solution in DMF was used. The tested organisms were two gram positive bacteria viz., Bacillus subtilis, Staphylococcus aureus, E-Coli and two gram negative bacteria viz., Escherichia coli, Pseudomonas aerogenasa and unicellular fungi as candida albicans. The bacteria and fungi were maintained on nutrient agar medium and Czapeks Dox agar medium, respectively. The agar media were inoculated with different test microorganisms. After $24 \mathrm{~h}$ of incubation at $30^{\circ} \mathrm{C}$ for bacteria and $48 \mathrm{~h}$ of incubation at $28^{\circ} \mathrm{C}$ for fungi, the diameter of inhibition zone $(\mathrm{mm})$ was measured. A reference standard for both gram positive and gram negative bacteria was made by dissolving accurately weighted quantity of Amikacin in sterile distilled water, separately. 


\section{Results and Discussion}

\section{Infrared and NMR studies of mdba}

The infrared spectrum of the mdba ligand (Table 2) exhibited a medium stretching frequency band for the carbonyl group at $1646 \mathrm{~cm}^{-1}$ and two strong bands at 1619 and $1583 \mathrm{~cm}^{-1}$ due to $v(\mathrm{C}=\mathrm{C})$. Furthermore, the IR spectrum displayed bands at 1267 and $1138 \mathrm{~cm}^{-1}$ assigned to the $\mathrm{O}$-ph and $\mathrm{O}-\mathrm{CH}_{3}$, respectively. The ${ }^{1} \mathrm{H}$ NMR spectrum of the mdba in deuterated DMSO-d6 showed doublet signal at $7.74 \mathrm{ppm}$ due to $-\mathrm{CH}=\mathrm{CH}-$, as well as multiplets at $8.15 \mathrm{ppm}$ due to the phenyl protons. Furthermore, a singlet signal at $3.81 \mathrm{ppm}$ due to $\left(\mathrm{O}-\mathrm{CH}_{3}\right)$ protons. X-ray crystallography data of the ligand $^{19}$ showed that the compound crystallizes with two molecules in the asymmetric unit. The mean planes of the two 3,4-dimethoxyphenyl groups in the two molecules make dihedral angles of 57.9(7) and $33.4(3)^{\circ}$. An extensive network of intermolecular $\mathrm{C}-\mathrm{H}$ , $\mathrm{O}$ hydrogen bonds stabilizes the crystal packing.

\section{Infrared, NMR and ESR studies of the mdba} complexes

Photochemistry offer simple and often highly selective route to organometallic compounds, overcoming large enthalpy which otherwise require the use of high temperatures or pressures ${ }^{20}$. When considering metal carbonyl compounds, the simplest photoreaction is the dissociative loss of $\mathrm{CO}$ from a mononuclear complex, $\left[\mathrm{M}(\mathrm{CO})_{5}\right]$ which, in the presence of a ligand, yields substituted derivatives; this is called photo-substitution. Photogeneration of $\mathrm{M}(\mathrm{CO})_{5}$ from $\mathrm{M}(\mathrm{CO})_{6}(\mathrm{M}=\mathrm{Cr}$, Mo, $\mathrm{W})$ and formation of substituted derivatives has been extensively studied ${ }^{21-23}$.

In the case of cluster carbonyl complexes, in addition to labialization of carbonyl group and substitution reaction, there is the possibility of metal-metal cleavage yielding lower nuclearity fragments; this is called photofrgmentation. Photophysical studies have shown that irradiation of $\mathrm{Ru}_{3}(\mathrm{CO})_{12}$ in the region of $390 \mathrm{~nm}$ leads essentially to fragmentation, whereas at shorter wavelengths $\sim 320 \mathrm{~nm}$ substitution reaction predominates $^{24,25}$. Many reactions are known but few are conducted using sunlight as the source of radiation due in part to low intensity of certain wavelengths as a result of being filtered through the atmosphere ${ }^{26}$.

Sunlight irradiation of the solution of $\left[\mathrm{Cr}(\mathrm{CO})_{6}\right]$ with mdba in benzene resulted in the formation of a mononuclear oxo-complex with molecular formula $\mathrm{CrC}_{42} \mathrm{H}_{44} \mathrm{O}_{11}$. The source of oxygen in the oxo complexes could be originated from the dissolved oxygen in the used solvent. The infrared spectrum of the chromium complex, 2, displayed the characteristic bands of mdba with the appropriate shifts due to complex formation (Table 4). The infrared spectrum of the complex also exhibited a non-ligand band at 762 $\mathrm{cm}^{-1}$ due to $\mathrm{Cr}=\mathrm{O} .^{27}$. The great shift of the ligand band from $1646 \mathrm{~cm}^{-1}$ to $1596 \mathrm{~cm}^{-1}$ suggested that the ligand coordinated to the chromium atom through carbonyl group and the $\beta-\mathrm{CH}=\mathrm{CH}$ oxidatively, i.e. with loss of one proton. The elemental analysis, Table 1 , and the available spectroscopic data, indicated that the chromium complex has square pyramidal configuration with chromium coordinated to two ligands molecules through $\mathrm{C}=\mathrm{O}$ groups and the carbon of $\mathrm{CH}=\mathrm{C}$ and bonded to one oxygen atoms as shown in Scheme 1. This structural arrangement would give a chromium species with $+4 \quad\left(d^{2}\right)$ formal oxidation states. Measurements of the magnetic susceptibility of solid $\mathrm{Cr}(\mathrm{O})(\mathrm{mdba}-\mathrm{H})_{2}$ at $298^{\circ} \mathrm{K}$ (Gouy method) gave an effective magnetic moment $\left(\mu_{\mathrm{eff}}\right)$ of $(2.783$ B.M). This value is close to the spin-only value of two unpaired electrons (2.82 B.M). Furthermore, the ESR spectra of the complex recorded as polycrystalline sample, Fig. 1, gives one broad isotropic signal centered approximately at around the free electron $\langle g\rangle$ value of 2.06361. The broadening of the spectra is due to spin relaxation ${ }^{28}$. Thus, it can be concluded that the chromium atom in the $\left[\mathrm{Cr}(\mathrm{O})(\mathrm{mdba}-\mathrm{H})_{2}\right]$ exist in square pyramidal environment, Scheme 1.

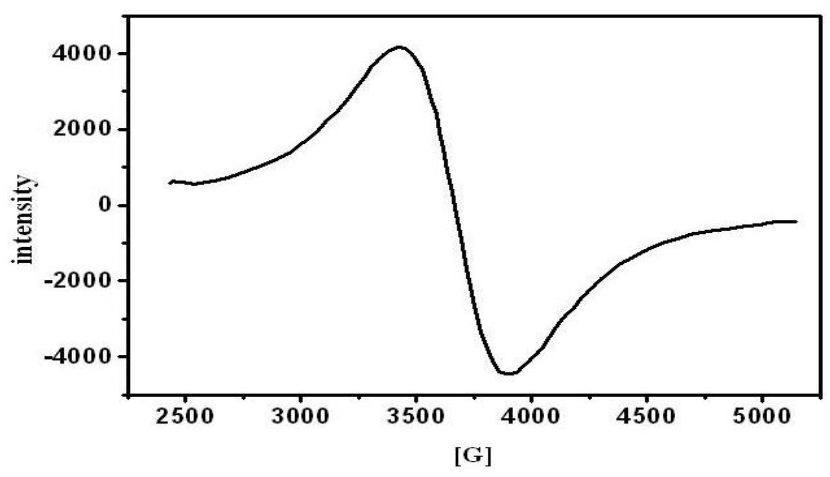

Fig. 1: The X-band ESR spectrum of polycrystalline $\left[\mathrm{CrO}(\mathrm{mdba}-\mathrm{H})_{2}\right]$ at room temperature.

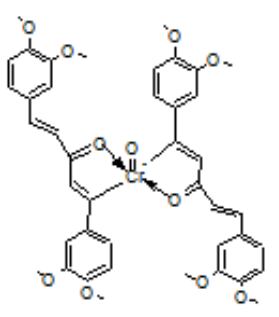

2

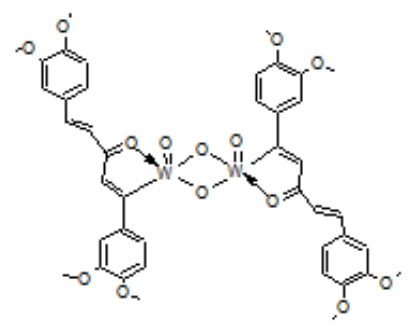

4

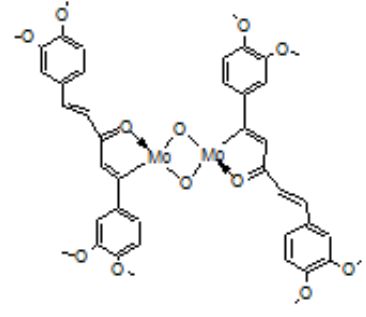

3

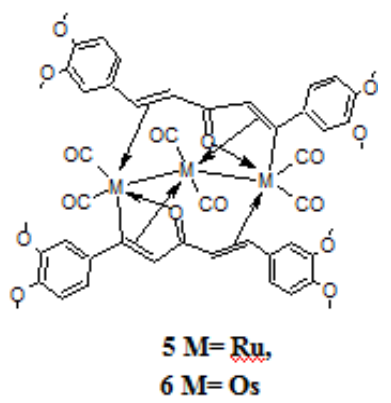

$6 \mathrm{M}=\mathrm{Os}$
Scheme 1 
The sun irradiation of a mixture of $\left[\mathrm{M}(\mathrm{CO})_{6}\right] ; \mathrm{M}=\mathrm{Mo}$ or $\mathrm{W}$ and mdba in dry benzene produced the binuclear complexes with molecular formula $\left[\mathrm{Mo}_{2} \mathrm{O}_{2}(\mathrm{mdpa}-\mathrm{H})_{2}\right]$, 3 and $\left[\mathrm{W}_{2} \mathrm{O}_{4}(\mathrm{mdpa}-\mathrm{H})_{2}\right], 4$. The IR spectra of the two complexes were similar with some differences suggesting different structures. The molybdenum complex exhibited a strong band at $1633 \mathrm{~cm}^{-1}$ due to the coordinated carbonyl group of the ligand with a shift of $13 \mathrm{~cm}^{-1}$. Moreover, non-ligand medium band at $757 \mathrm{~cm}^{-}$ ${ }^{1}$, attributed to Mo-O-Mo bonds. Such arrangement lead to the formation of paramagnetic oxo $\mathrm{Mo}(\mathrm{III}), d^{3}$ complex. Magnetic susceptibility measurement of the molybdenum complex at room temperature gave an effective magnetic moment of 4.16 B.M, i.e. 2.08 B.M. for each molybdenum atom in the binuclear complex. This value is smaller than the value of 3.87 B.M. for three unpaired electrons and may be due to antiferromagnetic coupling between the two molybdenum atoms. Formation of Mo(III) complex would occur through oxidative addition of $-\mathrm{CH}=\mathrm{CH}-$ group to Mo with loss of proton. According to the spectroscopic data, it can be suggested that Mo coordinated to the mdpa ligand through $\mathrm{C}=\mathrm{O}$ group and carbon from ethylene group after loss of one proton, and two bridging oxygen. The ESR spectra of the molybdenum complex recorded as polycrystalline sample at room temperature is shown in Figure 2. The Mo(III) complex exhibit an ESR signal at $\left(\mathrm{g}_{\|}=1.93961\right.$, $\mathrm{g}_{\perp}=1.97542$ ). From spectroscopic data, the structure of molybdenum complex would be a tetrahedral structure as presented in Scheme 1. On the other hand, photochemical reaction of $\mathrm{W}(\mathrm{CO})_{6}$ and mdba in ethanol under sun irradiation for $72 \mathrm{~h}$ produced the dinuclear oxo-complex $\left[\mathrm{W}_{2} \mathrm{O}_{4}(\mathrm{mdba}-\mathrm{H})_{2}\right], 4$. The infrared spectrum of 4 displayed stretching band at $812 \mathrm{~cm}^{-1}$ due to terminal $\mathrm{W}=\mathrm{O}$ bond $^{27}$. The infrared spectrum of the tungsten complex displayed a band at $1652 \mathrm{~cm}^{-1}$ due to the ligand $v(\mathrm{C}=\mathrm{O})$ stretching frequency, in addition to a new band at $763 \mathrm{~cm}^{-1}$ due to $\mathrm{W}-\mathrm{O}-\mathrm{W}$ bonds, respectively ${ }^{27}$. The $\mathrm{W}(\mathrm{V})$ signal has $\mathrm{g}$ values $\left(\mathrm{g}_{\|}=\right.$ 2.00709, $\left.\mathrm{g}_{\perp}=2.00958\right)$. The spectroscopic data available suggested that the tungsten complex, $\mathbf{4}$, is a dinuclear complex where each $\mathrm{W}$ atom coordinated to the ligand though carbonyl group of the ligand and carbon from ethylene group after loss of one proton, two bridging oxygen and terminal oxygen. Such arrangement leads to the formation of square pyrimidal structure complex where the sixth position available for weakly coordinated ethanol solvent (from crystallization) and can be lost by heating. The complex would be paramagnetic with the $\mathrm{W}(\mathrm{V}), d^{l}$. Magnetic susceptibility measurement of the tungsten complex at room temperature gave an effective magnetic moment of 3.39 B.M., i.e. 1.7 B.M. for each tungsten atom in the binuclear complex. The ESR spectra of the tungsten complex recorded as polycrystalline sample at room temperature is shown in Figure 2. The sharp signal at $\langle\mathrm{g}\rangle$ value of 2.009 suggest the presence of one unpaired electron in each tungsten atom of the complex not coupled with its environment. The proposed structure of
4 according to spectroscopic data, mass spectra and elemental analysis is shown in Scheme 1.

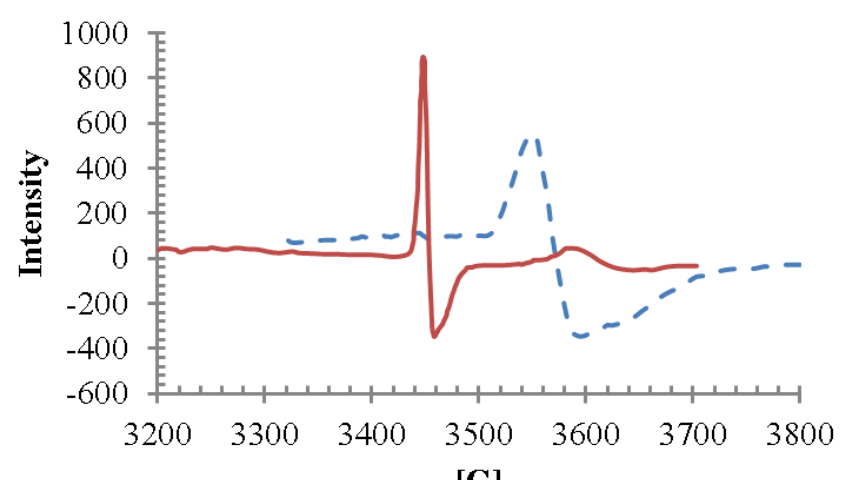

[G]

Fig. 2: The X-band ESR spectrum of polycrystalline (----) $\left[\mathrm{Mo}_{2} \mathrm{O}_{2}(\mathrm{mdba}-\mathrm{H})_{2}\right]$ and $(-)\left[\mathrm{W}_{2} \mathrm{O}_{4}(\mathrm{mdba}-\mathrm{H})_{2}\right]$ at room temperature.

Sun irradiation of $\left[\mathrm{M}_{3}(\mathrm{CO})_{12}\right], \mathrm{M}=\mathrm{Ru}$ or Os with mdba in ethanol results in the formation of the two metal clusters, $\mathrm{Ru}_{3}(\mathrm{CO})_{6}(\mathrm{mdba}-\mathrm{H})_{2}, \mathbf{5}$ and $\mathrm{Os}_{3}(\mathrm{CO})_{6}(\mathrm{mdba}-$ $\mathrm{H})_{2}, \mathbf{6}$, as predominant products, based on the elemental analysis and mass spectra. This indicates that two ligand molecules are coordinated to three ruthenium atoms. The FTIR spectra of both complexes exhibited one medium and two strong bands in the metal carbonyl stretching region, (Table 2), in addition to the bands of the ligand with appropriate shift due to complex formation. The fewer bands appeared for six M-CO groups indicate that the two complexes are symmetric. The structural distortion of a bound alkene can be detected by ${ }^{1} \mathrm{H}-\mathrm{NMR}$. The $\mathrm{J}_{\mathrm{CH}}$ of alkene like $\mathrm{sp}^{2}$ carbon is around $16.0 \mathrm{~Hz}$ where $\mathrm{sp}^{3}$ carbon have a $\mathrm{J}_{\mathrm{CH}}$ around $12.0 \mathrm{~Hz}$. ${ }^{1} \mathrm{H}-\mathrm{NMR}$ of both complexes showed signals similar to the ligand with considerable shift due to coordination to $\pi$-coordination of the double bond of the $\mathrm{CH}=\mathrm{CH}$ group to the metal atom, the signals of the olefin protons are considerably shifted to higher fields up to $\delta 6.69(\mathrm{~J}=14.7)$ and $6.68(\mathrm{~J}=9.0) \mathrm{ppm}$ for ruthenium and osmium complexes, respectively as compared to respective values of 7.30 and $7.74 \mathrm{ppm}(\mathrm{J}=$ $15.8 \mathrm{~Hz}$ ) for the initial ligand. Magnetic measurement of the complex at $298 \mathrm{~K}$ gave an effective magnetic moment $\mu_{\text {eff }}$ of $1.70 \mathrm{BM}$ for each of the two ruthenium atom which is close to the spin-only moment of an unpaired electron (1.73 BM). The ESR spectra of the

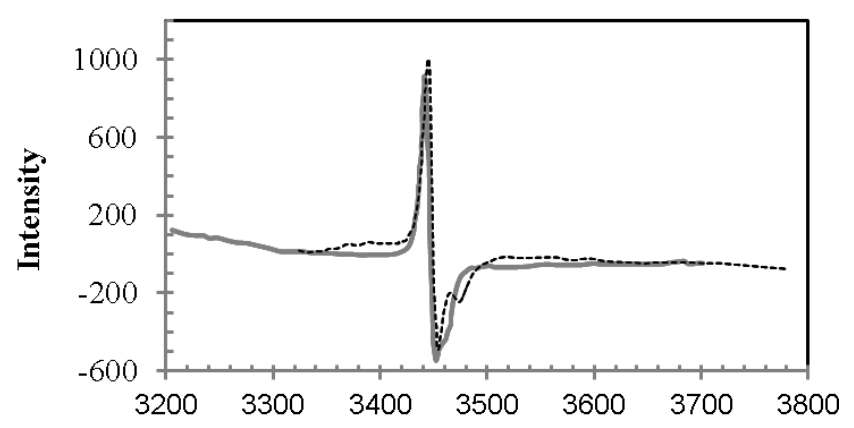

[G]

Fig. 3: The $\mathrm{X}$-band ESR spectrum of polycrystalline (-) $\left[\mathrm{Ru}_{3}(\mathrm{CO})_{6}(\mathrm{mdba}-\mathrm{H})_{2}\right]$ and $(---)\left[\mathrm{Os}_{3}(\mathrm{CO})_{6}(\mathrm{mdba}-\mathrm{H})_{2}\right]$ at room temperature 
complexes 5 and 6 are shown in Fig. 3.

According to the spectroscopic data available, the suggested structures of the ruthenium (5) and osmium (6) complexes are as shown in Scheme 1. The organic ligand in complexes realizes different coordination modes forming five-membered oxaruthenacycle, Each ligand chelates one of the terminal ruthenium atoms through $\mathrm{C}=\mathrm{O}$ and $\mathrm{Ph}-\mathrm{CH}=\mathrm{CH}$ forming the fivemembered ring. The olefin bonds of each ligand that do not take part in chelation are $\pi$ coordinated to the terminal ruthenium atoms at opposite edges of the metal chain. These five-membered chelate oxaruthenacycles are formed via oxidative addition of a ruthenium atom to the $\mathrm{C}_{\beta}-\mathrm{H}$ bond with simultaneous coordination of the keto oxygen electron lone pair. Further, acting as ligand, the oxaruthenacycle can form $\eta^{3}$ complexes through the $\mathrm{C}=\mathrm{C}$ bond and the $\mathrm{Ru}$ atom. Furthermore, each ruthenium atom coordinates two carbonyl ligands. This coordination type results in a distorted octahedral structure with completely filled 18-electrons shell for each ruthenium atom fulfilling EAN rule.

\section{UV-vis studies}

The absorption spectra of mdba and its complexes in DMSO are shown in Figure 4. The ligand has two bands at 230 and $385 \mathrm{~nm}$ due to $\pi-\pi^{*}$ and $n-\pi^{*}$ transitions. It is clear that the bands due to the $n-\pi^{*}$ transition in the ligand shows a large change in intensity and position upon coordination. This indicates the participation of the carbonyl group of the ligand in the complex formation. In the chromium, molybdenum and tungsten, the band at $385 \mathrm{~nm}$ is shifted to 350,345 and $355 \mathrm{~nm}$, respectively, in addition to a new band at $283 \mathrm{~nm}$. In ruthenium and osmium complexes, the spectra were similar and show a high decrease in intensity.

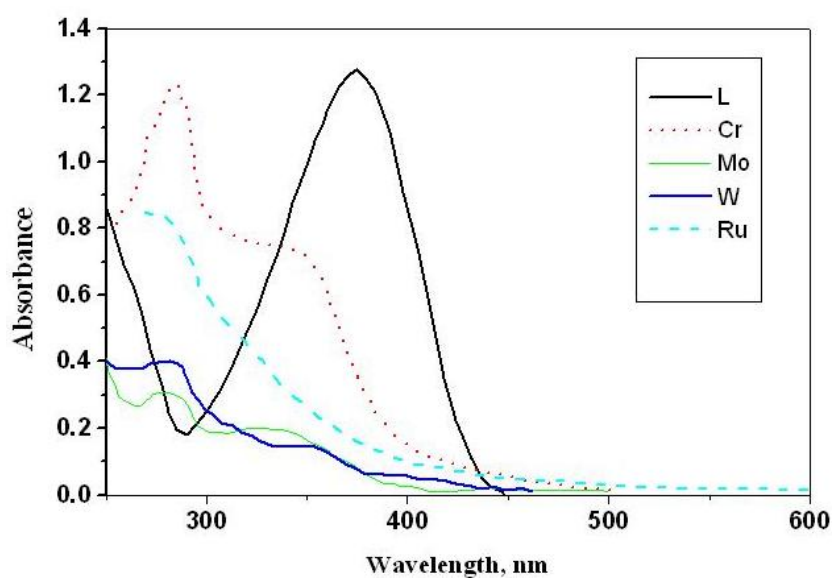

Fig. 4: Uv-Vis spectra of mdba and its complexes in DMSO: mdba $(--), \quad[\mathrm{CrO}(\mathrm{mdba}-\mathrm{H}) 2 \quad(\cdots), \quad[\mathrm{Mo} 2 \mathrm{O} 2(\mathrm{mdba}-\mathrm{H}) 2] \quad(----) \quad$ and [Os3(CO)6(mdba-H)] (-----).

\section{Thermal studies}

The thermal measurements of the complexes were carried out using thermogravimetric (TG) technique in order to study its thermal stability. The TG and DTG plots of the complexes exhibited overlapping decomposition steps. The ligand shows three decomposition steps. The first step occurred in the
177.5-392. $1^{\circ} \mathrm{C}$ range with the net loss of $46.96 \%$ which consisted with the loss of $\mathrm{C}_{10} \mathrm{H}_{11} \mathrm{O}_{2}$. The second and third overlapped steps occurred in the 392.1-507.5 and $508.8-712.3^{\circ} \mathrm{C}$, represent the loss of the rest of the molecule, $\mathrm{C}_{11} \mathrm{H}_{11} \mathrm{O}_{3}$, Figure 5. It can be noticed that the ligand is stable up to $200^{\circ} \mathrm{C}$. The $\mathrm{TG}$ plot of $\mathrm{CrO}$ (mdba$\mathrm{H})_{2}$ showed that the complex decomposed in three steps. The first step occurred in the range of $50-290^{\circ} \mathrm{C}$ with weight loss of $17.65 \%$ and would be due to loss of dimethoxyphenyl moiety $\left(\mathrm{C}_{8} \mathrm{H}_{9} \mathrm{O}_{2}\right)$. The second step $\left(291-520^{\circ} \mathrm{C}\right)$ also occurred with loss of $17.65 \%$ due to loss of another dimethoxyphenyl group. The two lost dimethoxy-phenyl group may be the groups attached to the coordinated carbon with loss of proton. On the other hand, the third step occurred in the temperature range $\left(521-930^{\circ} \mathrm{C}\right)$ with the weight loss of $34.64 \%$ (calc. $35.30 \%$ ) due to the loss of two dimethoxy-phenyl group leaving residue of $29.12 \%$ (calc. $29.38 \%$ ) consisted with $\mathrm{CrOC}_{10} \mathrm{H}_{6} \mathrm{O}_{2}$ species. The molybdemum complex showed an overlapped decompositions ended at $850^{\circ} \mathrm{C}$ leaving a residue of $19.6 \%$ due to two molybdenum, Table 3.

The TG plot of tungsten complex shows three decomposition steps, Figure 5. The first two steps occurred in the temperature range $\left(50-450^{\circ} \mathrm{C}\right)$ due to the loss of two dimethoxy-phenyl group similar to the chromium and molybdenum complexes. In the third step, the rest of the organic compound decomposed leaving a residue of $39.66 \%$ (calc. $40.77 \%$ ) due to two $\mathrm{WO}_{3}$.

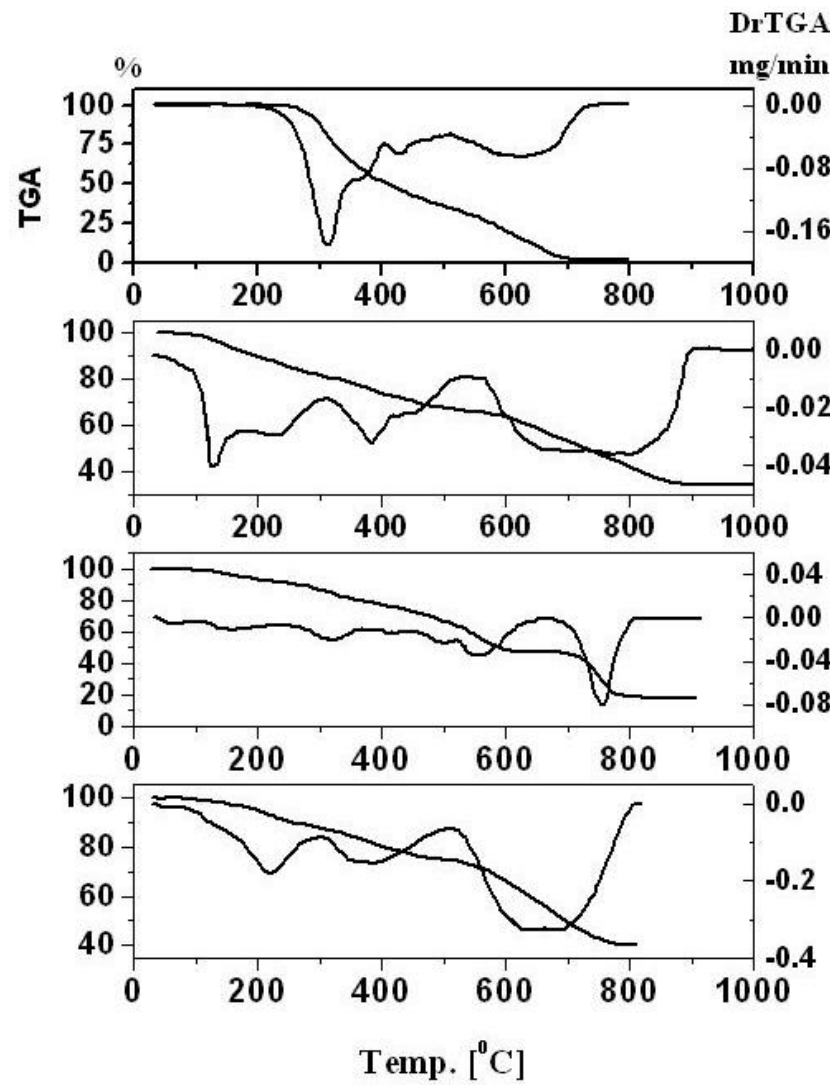

Fig. 5: TG and DTG plots of mdba ligand and its $\mathrm{Cr}$, Mo and W complexes. 
The TG plot of the ruthenium and osmium complexes showed that the complexes are thermally unstable than the ligand itself. The ruthenium complex first loss six $\mathrm{CO}$ molecules in the temperature range of $\left(50-200^{\circ} \mathrm{C}\right)$ and the organic ligand decomposed in the temperature range $\left(200-595^{\circ} \mathrm{C}\right)$ leaving a residue of $16.98 \%$ (calc.17.14\%) consisted with two ruthenium atoms, Table 3. The TG plot of osmium complex exhibited three decomposition steps, Figure 6, with decomposition of the six $\mathrm{CO}$ molecules in the temperature range (50$\left.180^{\circ} \mathrm{C}\right)$. The second and the third steps occurred in the temperature range $\left(200-530^{\circ} \mathrm{C}\right)$ represent the decomposition of rest of the complex leaving no residue.

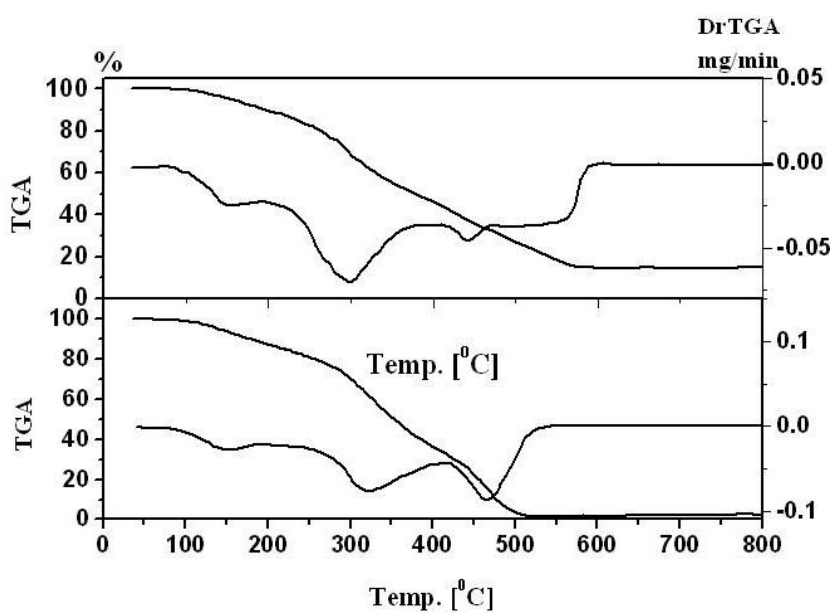

Fig. 6: TG and DTG plots of Ru and Os complexes.

\section{Antimicrobial activity}

The synthesized mdba ligand and its complexes were screened for their antibacterial activity against two gram positive bacteria, two gram negative bacteria and fungi candida albicans ${ }^{12,29}$. The inhibition zone produced by each compound was measured in $\mathrm{mm}$. The results of antibacterial studies are given in Table 4. All the tested complexes showed antimicrobial activity. mdba ligand has high activity towards Bacillus subtillus, S. aureus, EColi and C. albicans. Chromium complex, 2, exhibited weak antimicrobial activity. The rest of the complexes exhibited moderate activity compared to the standard Amikacin.

\section{Conclusion}

Five new complexes were isolated from the interaction of methoxylatd dibezylideneacetone ligand (mdba) with $\mathrm{M}(\mathrm{CO})_{6} \mathrm{M}=\mathrm{Cr}$, Mo or $\mathrm{W}$ and $\mathrm{M}_{3}(\mathrm{CO})_{12} \mathrm{M}=\mathrm{Ru}$ or Os using sun irradiation. Sun irradiation was found to be an excellent source of energy for preparing new interesting species from the metal carbonyls. An oxo-mononuclear derivative $\left[\mathrm{CrO}(\mathrm{mdba}-\mathrm{H})_{2}\right]$ was isolated from the interaction of mdba with $\left[\mathrm{Cr}(\mathrm{CO})_{6}\right]$. On the other hand, a binuclear derivatives $\left[\mathrm{Mo}_{2} \mathrm{O}_{2}(\mathrm{mdba}-\mathrm{H})_{2}\right]$ and $\left[\mathrm{Mo}_{2} \mathrm{O}_{2}(\mathrm{mdba}-\mathrm{H})_{2}\right]$ were isolated from the corresponding reactions of molybdenum and tungsten carbonyl, respectively. In these complexes, the ligand act as bidntate ligand and coordinated though oxygen of the keto group and oxidatively through one carbon of the olefin group and no participation of the olefin bond. Furthermore, cluster complexes of group 8 metal carbonyls were isolated under sunlight irradiation where the one M-M bond was broken and the ligand exhibited different modes of coordination.

Table 1: Physical characterization of mdba and its complexes.

\begin{tabular}{|c|c|c|c|c|c|c|c|}
\hline \multirow{3}{*}{$\begin{array}{l}\text { Comp. } \\
\text { No. }\end{array}$} & \multirow{3}{*}{$\begin{array}{l}\text { Reaction } \\
\text { time, h }\end{array}$} & \multirow{3}{*}{$\begin{array}{l}\text { M.P./ } \\
\text { Color }\end{array}$} & \multirow{3}{*}{ (\% yield $)$} & \multirow{3}{*}{ M.F./(M wt) } & \multirow{2}{*}{\multicolumn{3}{|c|}{$\begin{array}{c}\text { Elemental analysis } \\
\text { Calc. (Found) }\end{array}$}} \\
\hline & & & & & & & \\
\hline & & & & & $\% \mathrm{C}$ & $\% \mathrm{H}$ & $\% \mathrm{M}$ \\
\hline 1 & ----- & $\begin{array}{c}72-74 \\
\text { Yellow }\end{array}$ & $\begin{array}{c}\text { Ethanol } \\
(86)\end{array}$ & $\begin{array}{c}\mathrm{C}_{21} \mathrm{H}_{22} \mathrm{O}_{5} \\
354.39\end{array}$ & $\begin{array}{c}71.17 \\
(71.09)\end{array}$ & $\begin{array}{c}6.25 \\
(6.34) \\
\end{array}$ & - \\
\hline 2 & 48 & $\begin{array}{c}>228-230 \\
\text { (shr) } \\
\text { Green }\end{array}$ & $\begin{array}{l}\text { Ethanol } \\
\text { (74) }\end{array}$ & $\begin{array}{l}\mathrm{CrC}_{42} \mathrm{H}_{42} \mathrm{O}_{11} \\
\quad 774.77\end{array}$ & $\begin{array}{c}63.62 \\
(63.77)\end{array}$ & $\begin{array}{l}5.59 \\
(5.44)\end{array}$ & - \\
\hline 3 & 48 & $\begin{array}{c}>90-92 \\
\text { (decomp) } \\
\text { Brown }\end{array}$ & $\begin{array}{c}\text { Ethanol } \\
(82)\end{array}$ & $\begin{array}{l}\mathrm{Mo}_{2} \mathrm{C}_{42} \mathrm{H}_{42} \mathrm{O}_{12} \\
930.65\end{array}$ & $\begin{array}{c}54.03 \\
(54.12)\end{array}$ & $\begin{array}{l}4.75 \\
(4.76)\end{array}$ & - \\
\hline 4 & 72 & $\begin{array}{c}>284-286 \\
\text { (decomp) } \\
\text { Brown }\end{array}$ & $\begin{array}{c}\text { Ethanol } \\
(80)\end{array}$ & $\begin{array}{c}\mathrm{W}_{2} \mathrm{C}_{42} \mathrm{H}_{42} \mathrm{O}_{14} \\
1138.45\end{array}$ & $\begin{array}{c}45.46 \\
(45.59)\end{array}$ & $\begin{array}{l}4.00 \\
(3.98)\end{array}$ & - \\
\hline 5 & 72 & $\begin{array}{c}>150-152 \\
\text { (shr) } \\
\text { Brown }\end{array}$ & $\begin{array}{l}\text { Ethanol } \\
(75)\end{array}$ & $\begin{array}{c}\mathrm{Ru}_{3} \mathrm{C}_{48} \mathrm{H}_{42} \mathrm{O}_{16} \\
1178.04\end{array}$ & $\begin{array}{c}48.33 \\
(48.62)\end{array}$ & $\begin{array}{c}3.43 \\
(3.51)\end{array}$ & - \\
\hline 6 & 72 & $\begin{array}{c}>114-116 \\
\text { (decomp) } \\
\text { Brown }\end{array}$ & $\begin{array}{c}\text { Ethanol } \\
(92)\end{array}$ & $\begin{array}{l}\mathrm{Os}_{3} \mathrm{C}_{48} \mathrm{H}_{42} \mathrm{O}_{16} \\
1445.52\end{array}$ & $\begin{array}{c}40.04 \\
(39.93)\end{array}$ & $\begin{array}{l}3.82 \\
(3.76)\end{array}$ & - \\
\hline
\end{tabular}


Table 2. Spectroscopic data for mdba and its complexes.

\begin{tabular}{|c|c|c|c|c|}
\hline $\begin{array}{l}\text { Comp. } \\
\text { No. }\end{array}$ & $\begin{array}{c}\mathrm{IR} \\
\mathrm{KBr}, v_{\max }\left(\mathrm{cm}^{-1}\right)\end{array}$ & $\begin{array}{l}{ }^{1} \mathrm{H}-\mathrm{NMR} \\
\delta(\mathbf{p p m})\end{array}$ & $\begin{array}{c}{ }^{13} \mathrm{C}-\mathrm{NMR} \\
\delta(\mathrm{ppm}) \\
\end{array}$ & MS: $\mathbf{m} / \mathbf{e}(\%)$ \\
\hline 1 & $\begin{array}{l}v_{\mathrm{C}=\mathrm{O}}\left(1702 \mathrm{~cm}^{-1}\right) \\
v_{\mathrm{C}=\mathrm{C}}\left(1619 \mathrm{~cm}^{-1}\right)\end{array}$ & $\begin{array}{l}3.81 \quad(\mathrm{~s}, \\
\left.4 \mathrm{OCH}_{3}\right), \\
7.19 \quad(\mathrm{~m}, \\
6 \mathrm{H} \mathrm{Ar}) \\
7.74 \quad(\mathrm{~d}, \\
\mathrm{CH}=\mathrm{CH}, \\
\mathrm{J}=15.8 \\
\mathrm{~Hz})\end{array}$ & $\begin{array}{l}\mathrm{C}_{3}(188.020), \mathrm{C}_{3}^{\prime}(151.040), \\
\mathrm{C}_{4}{ }_{4}(148.983), \quad \mathrm{C}^{\prime}{ }_{1} \\
(127.541), \mathrm{C}_{2}{ }_{2}(123.776), \\
\mathrm{C}_{5}{ }_{5} \quad(123.127), \quad \mathrm{C}^{\prime}{ }_{6} \\
(120.644), \mathrm{C}_{8}{ }_{8}(38.954), \mathrm{C}^{\prime} 7 \\
(39.22), \mathrm{C}_{1}(110.557), \mathrm{C}_{2} \\
(111.645), \mathrm{C}_{4}(55.618), \mathrm{C}_{5} \\
(55.556)\end{array}$ & $\begin{array}{l}{[\mathrm{M}+1] 355(15.1), 354(62.8), 323(23.3),} \\
295(12.8), 264(14.0), 221 \quad(5.8), 217 \\
(12.8), 191(18.6), 163(23.3), 160(18.6), \\
151(100), 138(30.2), 133(22.1), 132 \\
(37.2), 131(15.1), 105(32.6), 103(19.8), \text {, } \\
91(52.3), 90(41.9), 77(80.2), 63(72.1), 52 \\
(20.9)\end{array}$ \\
\hline 2 & $\begin{array}{l}\mathrm{C}_{42} \mathrm{H}_{42} \mathrm{O}_{11} \mathrm{Cr} \\
v_{\mathrm{C}=\mathrm{O}}\left(1718 \mathrm{~cm}^{-1}\right) \\
v_{\mathrm{C}=\mathrm{C}}\left(1595 \mathrm{~cm}^{-1}\right) \\
v_{\mathrm{CV}=\mathrm{O}}\left(761 \mathrm{~cm}^{-1}\right)\end{array}$ & $\begin{array}{l}3.79 \quad(\mathrm{~s}, \\
\left.4 \mathrm{OCH}_{3}\right), \\
7.16 \quad(\mathrm{~m}, \\
\text { 6H.Ar), } \\
7.69 \quad(\mathrm{~d}, \\
\mathrm{CH}=\mathrm{CH}, \\
\mathrm{J}=15.6 \\
\mathrm{~Hz})\end{array}$ & - & 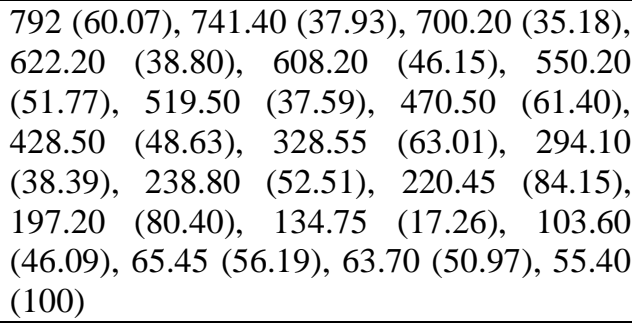 \\
\hline 3 & $\begin{array}{l}\mathrm{C}_{42} \mathrm{H}_{42} \mathrm{O}_{12}(\mathrm{Mo})_{2} \\
v_{\mathrm{C}=\mathrm{O}}\left(1710 \mathrm{~cm}^{-1}\right) \\
v_{\mathrm{C}=\mathrm{C}}\left(1588 \mathrm{~cm}^{-1}\right) \\
\mathrm{Mo}_{2} \mathrm{O}_{2} 955,854 \\
\mathrm{~cm}^{-1}\end{array}$ & $\begin{array}{l}3.81 \quad(\mathrm{~s}, \\
\left.4 \mathrm{OCH}_{3}\right) \\
7.74 \quad(\mathrm{~d}, \\
\mathrm{CH}=\mathrm{CH}, \\
\mathrm{J}=15.8 \\
\mathrm{~Hz}), 7.19 \\
(\mathrm{~m}, \\
\text { 6H.Ar) }\end{array}$ & - & 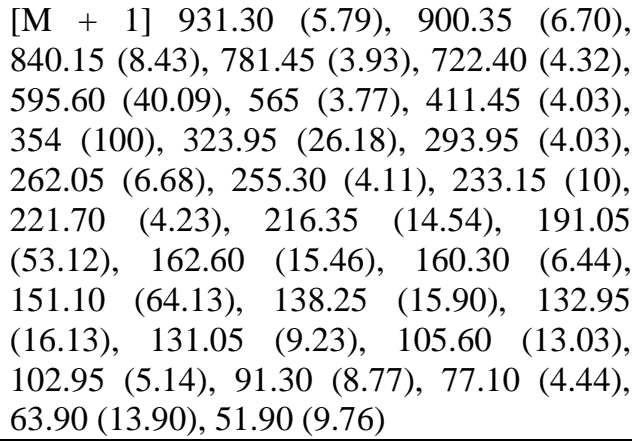 \\
\hline 4 & $\begin{array}{l}\mathrm{C}_{42} \mathrm{H}_{42} \mathrm{O}_{14} \mathrm{~W}_{2} \\
v_{\mathrm{C}=\mathrm{O}}\left(1710 \mathrm{~cm}^{-1}\right) \\
\mathrm{v}_{\mathrm{C}=\mathrm{C}}\left(1652 \mathrm{~cm}^{-1}\right) \\
\mathrm{W}_{2} \mathrm{O}_{2} \quad 975,812 \\
\mathrm{~cm}^{-1}\end{array}$ & $\begin{array}{l}3.81 \quad(\mathrm{~s}, \\
\left.4 \mathrm{OCH}_{3}\right), \\
6.97 \quad(\mathrm{~m}, \\
6 \mathrm{H} . \mathrm{Ar}), \\
7.05 \quad(\mathrm{~d}, \\
\mathrm{CH}=\mathrm{CH}, \\
\mathrm{J}=12 \\
\mathrm{~Hz})\end{array}$ & & 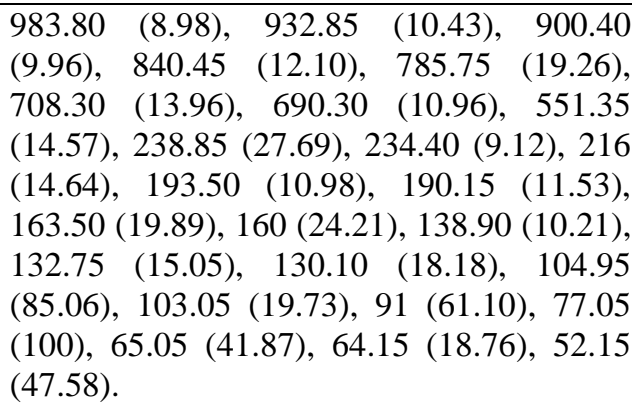 \\
\hline 5 & $\begin{array}{l}\mathrm{C}_{48} \mathrm{H}_{38} \mathrm{Ru}_{3} \mathrm{O}_{16} \\
v_{\mathrm{C}=\mathrm{O}}\left(1725 \mathrm{~cm}^{-1}\right) \\
v_{\mathrm{C}=\mathrm{C}}\left(1598 \mathrm{~cm}^{-1}\right) \\
\mathrm{Ru}-\mathrm{CO} \quad 2119, \\
2024,1945 \mathrm{~cm}^{-1}\end{array}$ & $\begin{array}{l}3.77 \quad(\mathrm{~s}, \\
\left.4 \mathrm{OCH}_{3}\right), \\
6.67 \quad(\mathrm{~m}, \\
6 \mathrm{H} . \mathrm{Ar}) \\
7.001 \quad(\mathrm{~d}, \\
\mathrm{CH}=\mathrm{CH}, \\
\mathrm{J}=14.7 \\
\mathrm{~Hz})\end{array}$ & & 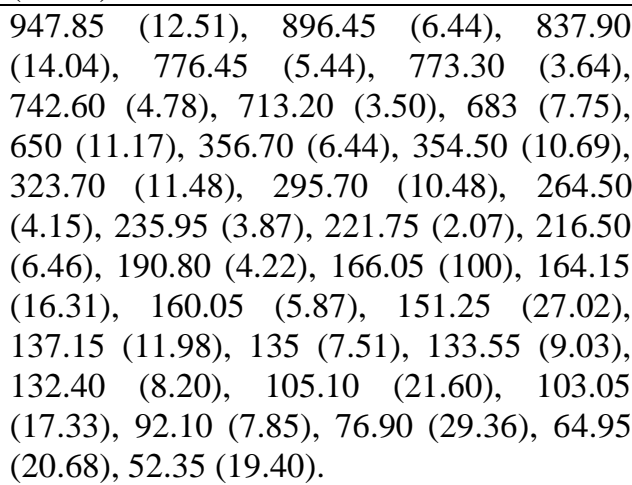 \\
\hline 6 & $\begin{array}{l}\mathrm{C}_{48} \mathrm{H}_{38} \mathrm{Os}_{3} \mathrm{O}_{16} \\
v_{\mathrm{C}=\mathrm{O}}\left(1709 \mathrm{~cm}^{-1}\right) \\
v_{\mathrm{C}=\mathrm{C}}\left(1635 \mathrm{~cm}^{-1}\right) \\
\text { Os-CO 2125, } \\
2036,1955 \mathrm{~cm}^{-1}\end{array}$ & $\begin{array}{l}3.79(\mathrm{~s}, \\
4 \mathrm{OCH})_{3}, \\
6.68(\mathrm{~m}, \\
6 \mathrm{H} . \mathrm{Ar}), \\
7.048(\mathrm{~d}, \\
\mathrm{CH}=\mathrm{CH}, \\
\mathrm{J}=9 \mathrm{~Hz})\end{array}$ & $\begin{array}{l}\mathrm{C}_{3}(189.530), \mathrm{C}_{3}^{\prime}(150.845), \\
\mathrm{C}_{4}^{\prime} \quad(148.949), \mathrm{C}_{1}^{\prime} \\
(127.667), \mathrm{C}_{13}(131.714), \\
\mathrm{C}_{2}^{\prime} \quad(125.031), \quad \mathrm{C}_{5} \\
(122.459), \mathrm{C}_{6}{ }_{6}(121.754), \mathrm{C}_{2} \\
(111.652), \mathrm{C}_{1}(110.756), \mathrm{C}_{8}{ }_{8} \\
(38.932), \mathrm{C}_{7}(39.20), \mathrm{C}_{11} \\
(163.571), \mathrm{C}_{12}(159.916), \mathrm{C}_{9} \\
(105.728), \mathrm{C}_{10}(98.613)\end{array}$ & 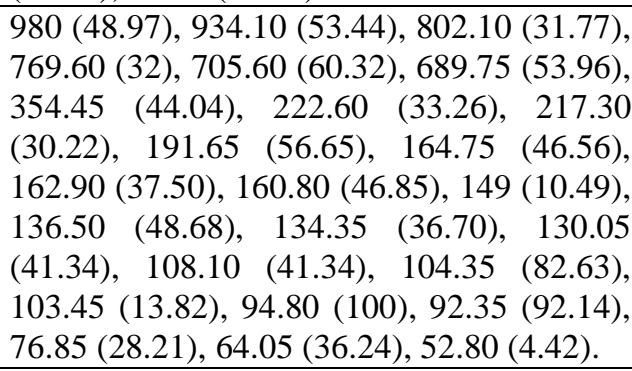 \\
\hline
\end{tabular}


Table 3. Thermal analysis data of mdba and its complexes.

\begin{tabular}{|c|c|c|c|c|c|}
\hline $\begin{array}{c}\text { Compound } \\
\text { No. }\end{array}$ & Molecular formula & $\begin{array}{l}\text { Molecular } \\
\text { Weight }\end{array}$ & $\begin{array}{c}\text { Decomposition } \\
\text { Temp. }{ }^{0} \mathrm{C}\end{array}$ & $\begin{array}{c}\text { Weight Losses } \\
\%\end{array}$ & $\begin{array}{l}\text { Solid residue } \\
(\%) \\
\text { Calc. (found) }\end{array}$ \\
\hline 1 & $\mathrm{C}_{21} \mathrm{H}_{22} \mathrm{O}_{5}$ & 354.394 & $\begin{array}{l}177-392 \\
392-507 \\
509-716\end{array}$ & $\begin{array}{l}46.96 \\
17.97 \\
34.98\end{array}$ & --------- \\
\hline 2 & {$\left[\mathrm{Cr}(\mathrm{O})(\mathrm{mdba}-\mathrm{H})_{2}\right]$} & 774.77 & $\begin{array}{l}40-291 \\
291-521 \\
521-930\end{array}$ & $\begin{array}{l}17.98(17.7) \\
17.20(17.7) \\
35.45(35.48)\end{array}$ & $\begin{array}{l}\mathrm{CrOC}_{10} \mathrm{H}_{6} \mathrm{O}_{2} \\
29.12(29.38)\end{array}$ \\
\hline 3 & {$\left[\mathrm{Mo}_{2} \mathrm{O}_{2}(\mathrm{mdba}-\mathrm{H})_{2}\right]$} & 930.66 & $\begin{array}{l}40-310 \\
311-450 \\
455-595 \\
682-800\end{array}$ & $\begin{array}{l}15.6(14.73) \\
14.1(14.73) \\
23.64(24.68) \\
27.5(27.4)\end{array}$ & $\begin{array}{l}2 \mathrm{Mo} \\
20.6 \\
(19.6)\end{array}$ \\
\hline 4 & {$\left[\mathrm{~W}_{2} \mathrm{O}_{4}(\mathrm{mdba}-\mathrm{H})_{2}\right]$} & 1138.44 & $\begin{array}{l}50-248 \\
249-450 \\
471-795\end{array}$ & $\begin{array}{l}11.85(12.04) \\
12.12(12.04) \\
36.14(35.15)\end{array}$ & $\begin{array}{l}2 \mathrm{WO}_{3} \\
40.77(39.66)\end{array}$ \\
\hline 5 & {$\left[\mathrm{Ru}_{3}(\mathrm{CO})_{6}(\mathrm{mdba}-\mathrm{H})_{2}\right]$} & 1178.04 & $\begin{array}{l}50-200 \\
200-595\end{array}$ & $\begin{array}{l}14.83(14.26) \\
68.19(68.6)\end{array}$ & $\begin{array}{l}2 \mathrm{Ru} \\
16.98 \text { (17.14) }\end{array}$ \\
\hline 6 & {$\left[\mathrm{Os}_{3}(\mathrm{CO})_{6}(\mathrm{mdba}-\mathrm{H})_{2}\right]$} & 1445.52 & $\begin{array}{l}50-180 \\
180-530\end{array}$ & $\begin{array}{l}11.75(11.62) \\
88.24(88.38)\end{array}$ & ----- \\
\hline
\end{tabular}

Table 4. The inhibition zones $(\mathrm{mm})$ of mdba and its complexes. The activity of $2.5 \mathrm{mg} / \mathrm{ml}$ of the sample, Amikacin was used as standard.

\begin{tabular}{|l|c|c|c|c|c|}
\hline \multicolumn{1}{|c|}{ Sample } & B. subtillus & S. aureus & E. coli & P. aeruginosa & C. albicans \\
\hline$\left[\mathrm{CrO}(\mathrm{mdba}-\mathrm{H})_{2}\right]$ & 11 & -- & --- & --- & 11 \\
\hline$\left[\mathrm{Mo}_{2} \mathrm{O}_{2}(\mathrm{mdba}-\mathrm{H})_{2}\right]$ & 16.5 & --- & --- & 11 & 13.5 \\
\hline$\left[\mathrm{W}_{2} \mathrm{O}_{4}(\mathrm{mdba}-\mathrm{H})_{2}\right]$ & 12 & 12.5 & --- & --- & 12 \\
\hline$\left[\mathrm{Ru}_{3}(\mathrm{CO})_{6}(\mathrm{mdba}-\mathrm{H})_{6}\right]$ & 15 & 12 & 11 & 11 & 13.5 \\
\hline$\left[\mathrm{Os}_{3}(\mathrm{CO})_{6}(\mathrm{mdba}-\mathrm{H})_{2}\right]$ & 18.5 & 18 & 15 & 16 & 17 \\
\hline Mdba & 25 & 20.5 & 25 & 19 & 23 \\
\hline Amikacin & 29 & 31 & 34 & 32 & 25 \\
\hline
\end{tabular}

\section{References}

1) M. I. Rybinskaya, L. V. Rybin, S. V. Osintseva, F. M. Dolgushin, A. I. Yanovskii, and Yu. T. Struchkov (1995). Russ. Chem. Bull., 44: 154.

2) L. V. Rybin, S. V. Osintseva, E. A. Petrovskaya, A. Z. Kreindlin, F. M. Dolgushin, A. I. Yanovskii, P. V. Petrovskii, and M. I. Rybinskaya (2000). Russ. Chem. Bull., Int. Ed., 49: 1605.

3) L. V. Rybin, S. V. Osintseva, A. S. Batsanov, Yu. T. Struchkov, P. V. Petrovskii, and M. I. Rybinskaya (1993). Russ. Chem. Bull., 42: 1228.

4) L. V. Rybin, S. V. Osintseva, P. V. Petrovskii, M. I. Rybinskaya, F. M. Dolgushin, A. I. Yanovsky, and Yu. T. Struchkov (1994). J. Organomet. Chem.,479: 25.
5) L. V. Rybin, S. V. Osintseva, M. I. Rybinskaya, F. M. Dolgushin, A. I. Yanovsky, and Yu. T. Struchkov (1995). J. Organomet. Chem., 485: 253.

6) S. V. Osintseva,_F. M. Dolgushin, P. V. Petrovskii, N. A. Stelzer, A. Z. Kreindlin, L. V. Rybin, and M. I. Rybinskaya (2002). Russ. Chem.l Bull., Int. Ed. 51: 1754-1764.

7) H. Tanaka, H. Kawazura (1980). Bull Chem. Soc. Jpn. 53: 1743-1944.

8) T. Ukai, H. Kawazura, Y. Fishii., J. Bonnet, J.A. Ibers (1974). J. Organomet. Chem. 65: 253.

9) F. A. Jalón, B. R. Manzano, F. Gómez-de la Torre, A. M. López-Agenjo, A. M. Rodríguez, W. Weissensteiner, T. Sturm, J. Mahía and M. Maestro (2001). J. Chem. Soc., Dalton Trans., 2417-2424. 
10) H. Yamakoshi, H. Ohori, C. Kudo, A. Sato, N. Kanoh, C. Ishioka, H. Shibata, Y. Iwabuchi (2010). Bioorg Med Chem. 18(3):1083-1092.

11) L. Lin, Q. Shi, A.K. Nyarko, K.F.Bastow, C.C. Wu, C.Y.Su,C.C. Shih, K.H. Lee (2006). J Med Chem. 49(13):3963-72.

12) J.R. Fuchs, B. Pandit, D. Bhasin, J.P. Etter, N. Regan, D. Abdelhamid, C. Li, Lin J, P.K. Li (2009). Bioorg Med Chem Lett.; 19(7):2065-9.

13) A.A. Sammour, A. Raouf, M.A. El-Kasaby, M.A.I. Saleim (1973). Acta Chim. Acad. Scien. Hungaria, 78: 399-408.

14) M.M. Abdalla, M.A.I. Salem, A.M. Hataba (1979). Egypt J. Chem. 22, 223-229.

15) M.M. Abdalla, M.A.I. Salem, A.M. Hataba (1979). Egypt J. Chem. 22, 443-455.

16) A.A. Hamed, M.A.I. Salem, A.M. Hataba, I. Attia (1986). Ain Shams Sci. Bull. 16(A): 297-304.

17) M. M.H. Khalil, R. M. Ramadan, M. A.I. Salem, M. I. Marzouk, and M. S. Muftah (2011). Egy. J. Pure \& Appl. Sci., in press.

18) R.E. Cooper (1972). "Analytical Microbiology" F.W. Kavanageh (ed), Vol I \& II Academic Press, New York and London.
19) R. J. Butcher, J. P. Jasinski, H. S. Yathirajan, S. Bindya, B. Narayana and B. K. Sarojini (2007). Acta Cryst. E63, O3115.

20) P.C. Ford (1990). J. Organometa. Chem. 383: 339.

21) S. Sert; O.S. Senturk, F. Sarkkahya (2003). Trans. Met. Chem. 28: 133.

22) F. Sar1kahya, O.S. Senturk (2001). Syn. React. Inorg. Met. 31: 1843.

23) E. Subasi, H. Temel (2007). React. Inorg. Met. 37: 85-89.

24) M.F. Desroisers, D.A. Wink, R. Trautman, A.E., Friedman, P.C., Ford (1986). J. Am. Chem. Soc. 108: 1917.

25) J.B. Bentsn, M.S., Wrighton, J. Am (1987). Chem. Soc. 109: 4530.

26) D.C. Calabro and D.L. Lichtenberger (1982). J. Chem. Ed. 59: 686.

27) K. Nakamoto (1986). Infrared and Raman Spectra of Inorganic and Coordination Compounds, Fourth ed., Wiley, New York.

28) R.S. Drago (1986). Physical Methods in Chemistry, Saunders, Philadelphia.

29) A.W. Bauer, W.W.M. Kirby, J.C., Sherris, M. Turek (1966). Am. Clinic. Pathology 45: 493-496. 